\title{
Nucleosome Assembly Protein Gene
}

National Cancer Institute

\section{Source}

National Cancer Institute. Nucleosome Assembly Protein Gene. NCI Thesaurus. Code C26049.

A gene that encodes nucleosome assembly proteins, which are involved in the formation of the complex between histones and DNA in eukaryotic cells. 